BEDAH BUKU

Judul Buku :

\title{
Akuntansi Sektor Publik Akuntansi Keuangan Daerah
}

Penulis : Prof. Dr. Abdul Halim, MBA, Akt. Tahun/Edisi : 2004/Edisi Revisi. Halaman : $220+$ xiv hal.

Penerbit : Penerbit Salemba Empat, Jakarta.

\section{Syukriy Abdullah \\ Fakultas Ekonomi Universitas Syiah Kuala Banda Aceh}

Buku ini merupakan salah satu buku teks akuntansi yang menjelaskan konsep dan praktik akuntansi keuangan daerah (AKD) yang diterapkan di Indonesia sesuai dengan peraturan perundang-undangan tentang otonomi daerah. Sebagai pakar dalam penganggaran dan akuntansi pemerintahan (penulis adalah dosen senior di Fakultas Ekonomi Universitas Gadjah Mada), penulis menuangkan pengetahuan dan pengalamannya dalam sebuah urutan penulisan yang sistematis dan mudah dipahami, terutama oleh orang yang baru pertama sekali mengenal akuntansi, khususnya AKD.

Sistematika penulisan buku ini adalah sebagai berikut. Bab I merupakan bab pendahuluan, yang berisi uraian tentang manajemen keuangan di era sebelum dan sesudah berjalannya otonomi daerah (penulis menyebutnya era pra dan pasca reformasi). Penulis menjelaskan berbagai aturan yang mendasari pengelolaan keuangan daerah pada kedua era tersebut dan pergeseran yang kemudian terjadi hingga terciptanya kondisi seperti sekarang ini.

Bab II dan Bab III menjelaskan posisi AKD sebagai bagian dari manajemen keuangan daerah dan akuntansi. Uraian ini penting untuk menjawab berbagai pertanyaan yang sering muncul, terutama dari aparatur Pemerintah Daerah (Pemda) yang tidak memiliki latar belakang pengetahuan akuntansi. Akuntansi berbeda dengan anggaran, sehingga laporan keuangan Pemda (Laporan Perhitungan APBD, Neraca, dan Laporan Aliran Kas) juga berbeda dengan APBD. Penulis juga menjelaskan daur anggaran negara (APBN) dan APBD serta perubahan mendasar dalam APBD di masa pasca reformasi. Di sini dijelaskan mengenai pengertian akuntansi, lingkup dan tujuan akuntansi pemerintahan, lingkungan AKD, stakeholders, dan kelebihan akuntansi dibandingkan tatabuku yang dilaksanakan selama ini oleh Pemda.

Bab IV mencakup pengertian, sistem pencatatan, dasar dan siklus AKD. Single entry dan double entry dijelaskan dengan memberikan contoh sederhana. Begitu pula untuk kemudahan pemahaman tentang basis kas, akrual, kas modifikasian, dan akrual modifikasian diberikan contoh penjurnalan dalam jurnal umum. Uraian tentang siklus akuntansi dimulai dengan analisis transaksi, kemudian jurnal, posting, neraca saldo, jurnal penyesuaian, laporan keuangan, sampai pada neraca saldo setelah tutup buku.

Bab V menjelaskan tentang rekening-rekening (accounts) dalam laporan keuangan daerah, termasuk kodifikasi dan kebijakan akuntansi (definisi, pengakuan dan pengukuran). Rekening-rekening tersebut terdiri dari pendapatan, belanja, pembiayaan, utang, dan ekuitas dana (dalam akuntansi untuk bisnis disebut modal).

Bab VI secara spesifik menguraikan tentang akuntansi untuk Badan Usaha Milik Daerah (BUMD), yang dapat dipandang sebagai suatu pusat laba (profit center) bagi Pemda. Bab VII merupakan soal dan penyelesaiannya, yakni kasus faktual yang terjadi di Pemda, yang disederhanakan sedemikian rupa sehingga 
mudah dipahami bagaimana proses pencatatan transaksi sampai pada penyusunan laporan keuangan daerah dilakukan di satuan kerja, bagian keuangan dan Pemda sebagai entitas pelaporan tersendiri.

Secara umum dapat dikatakan bahwa buku ini memberikan penjelasan teknis paling lengkap dibanding buku-buku sejenis. Buku ini seakan-akan menjadi petunjuk teknis sekaligus panduan (guidance) bagi aparat Pemda yang melaksanakan penatausahaan dan akuntansi keuangan daerah (terutama biro/subbag/bidang anggaran, akuntansi, verifikasi, pemegang kas satuan kerja, dan Bawasda). Namun, buku ini bukanlah sebuah handbook, yang dapat menjelaskan semua aspek AKD. Lebih tepat jika buku ini disebut sebagai sebuah pengantar untuk AKD di Indonesia. Dibutuhkan buku yang lebih lengkap, tebal dan sophisticated untuk bisa menjelaskan semua permasalahan dan isu yang terdapat dalam AKD.

Beberapa kelebihan buku ini adalah (1) mengacu pada aturan yang berlaku di Indonesia saat ini, seperti UU No. 22 dan 29 tahun 1999, UU No. 17 tahun 2003, UU No. 1 tahun 2004, PP No. 105 dan 108 tahun 2000, dan terutama sekali Keputusan Menteri Dalam Negeri (Kepmendagri) No. 29 tahun 2002. Isi buku berfokus pada akuntansi keuangan dasar yang dibutuhkan di Pemda sehingga tidak teralu banyak membahas aspek akuntansi (bisnis) yang tidak relevan untuk diterapkan di Pemda; (2) menggunakan pendekatan praktik dalam menjelaskan pencatatan atas suatu transaksi, yakni didasarkan pada proses yang sesungguhnya terjadi di Pemda. Misalnya untuk penjurnalan didasarkan pada dokumen berupa SPM (dulu SPMU) dan SPJ; (3) bahasanya mudah dipahami karena tidak menggunakan istilah-istilah akuntansi yang sulit dimengerti oleh orang yang tidak memiliki latar belakang pendidikan akuntansi; dan (4) sistematika penulisan yang runtun mulai dari perubahan paradigma pengelolaan keuangan daerah sampai pada penyusunan laporan keuangan memudahkan pemahaman tentang esensi AKD sebagai bagian dari pelaksanaan anggaran yang transparan dan akuntabel.

Namun, yang namanya buku tentu tidak ada yang sempurna. Ada beberapa kekurangan buku ini, yang mungkin dapat dilengkapi dengan beberapa buku lain yang sejenis. Beberapa kekurangan tersebut di antaranya adalah (1) tidak menjelaskan lebih jauh bagaimana kelebihan dan kelemahan konsep basis kas modifikasian (modified cash basis) dan akrual modifikasian (modified accrual basis) serta penggunaan basis akrual pada masa yang akan datang. Basis akrual merupakan yang terbaik dalam akuntansi dan beberapa negara telah menerapkannya, seperti Selandia Baru, Australia, dan Inggris; (2) belum memasukkan konsepkonsep anggaran secara lengkap, seperti dokumen dan formulir serta proses penyusunan anggaran yang melibatkan eksekutif dan legislatif. Hal ini penting mengingat akuntansi yang dilaksanakan Pemda adalah akuntansi anggaran (budgetary accounting) sehingga analisis atas laporan keuangan Pemda nantinya sangat terkait dengan pemahaman tentang anggaran (APBD); (3) tidak menjelaskan implikasi pemeriksaan (auditing) dari laporan keuangan yang disusun oleh Pemda; dan (4) membutuhkan tambahan penjelasan tentang aspek pembuatan kebijakan akuntansi, seperti penyusutan (depresiasi), penilaian kembali aktiva tetap (revaluasi), penilaian persediaan, dan analisis laporan keuangan Pemda.

Secara substantif, buku Akuntansi Sektor Publik - Akuntansi Keuangan Daerah ini layak dan cocok digunakan sebagai buku pegangan utama untuk mata kuliah Akuntansi Sektor Publik di program S1 Akuntansi. Beberapa buku lain yang dapat digunakan sebagai tambahan adalah (1) Jones, Rowan \& Maurice Pendlebury. 2000. Public Sector Accounting. 5th edition. Harlow: Prentice Hall; (2) Freeman, Robert J. \& Craig D. Shoulders. 2003. Governmental and Nonprofit Accounting - Theory and Practice. Seventh edition. Upper Saddle River, NJ: Prentice-Hall; dan (3) Anthony, Robert N. \& David W. Young. 2003. Management Control in Nonprofit Organizations. Boston: McGraw-Hill Irwin.

Selain isi yang cukup bagus, secara fisik bentuk cover, setting, dan kertas yang digunakan pada buku ini cukup baik. Seperti edisi pertamanya, di pasaran buku ini cukup laris untuk ukuran buku teks akuntansi karena sampai beberapa kali mengalami cetak ulang. Untuk ukuran mahasiswa mungkin harganya agak mahal (sekitar Rp30.000-an), tetapi melihat kualitas isi dan tampilan buku, harga tersebut dapat dikatakan sepadan. Selamat menikmati. 